\title{
Population size of Cuban Parrots Amazona leucocephala and Sandhill Cranes Grus canadensis and community involvement in their conservation in northern Isla de la Juventud, Cuba
}

\author{
XIOMARA GÁLVEZ AGUILERA, VICENTE BEROVIDES ALVAREZ, \\ JAMES W. WILEY and JOSÉ RIVERA ROSALES
}

\begin{abstract}
Summary
The Cuban Sandhill Crane Grus canadensis nesiotes and Cuban Parrot Amazona leucocephala palmarum are considered endangered species in Cuba and the Isla de la Juventud (formerly Isla de Pinos). Coincident with a public education campaign, a population survey for these species was conducted in the northern part of the Isla de la Juventud on 17 December 1995, from o6hoo to 10hoo. Residents from throughout the island participated, manning 98 stations, with 1-4 observers per station. Parrots were observed at $60(61.2 \%)$ of the stations with a total of 1320 , maximum (without correction for duplicate observations), and 1100, minimum (corrected), individuals counted. Sandhill cranes were sighted at $38(38.8 \%)$ of the stations, with a total of 115 individuals. Cranes and parrots co-occurred at $20(20.4 \%)$ of the stations.
\end{abstract}

\section{Resúmen}

La grulla Grus canadensis nesiotes y la cotorra Amazona leucocephala palmarum son dos especies de aves cubanas amenazadas de extinción que ocurren en la parte Norte de la Isla de la Juventud, Cuba. Para ambas especies se organizó un conteo poblacional, donde de forma masiva participó toda la población de la Isla. El conteo se llevó a cabo de día 17 de diciembre de 1995, en 98 puntos de observación (PO), dispersos por todo el Norte de la Isla, entre las o6hoo y 1ohoo, con 1 a 4 observadores por punto. En 60 PO $(61.2 \%)$ se observaron cotorras, dando un total de 1320 individuos (sin corregir par posibles observaciones repetidas) y 1100 (corregido). En $38 \mathrm{PO}(38.8 \%)$ se detectaron grullas, dando un total de 115 individuos. Grullas y cotorras coocurrieron en el $20.4 \%$ de los $\mathrm{PO}$ en los Indios.

\section{Introduction}

The Cuban archipelago is comprised of two principal islands, Cuba and the Isla de la Juventud (formerly Isla de Pinos), and 4,195 smaller islands and cays. Almost all of these areas have been extensively modified since European discovery. At that time (1492), perhaps $70-90 \%$ of Cuba was covered with forests 
(Instituto Cubano de Geodesia y Cartografía 1978). By 1900, however, only 54\% was under forest, and by 1959 forested areas were reduced to only $13 \%$ of the land area. Since then, a national policy of reforestation has resulted in an increase in forest surface area, which in 1990 stood at about $18.7 \%$ (Cuevas 1997).

As habitat was altered, so were faunal communities. In addition, many species were important game species or had commercial value. Still other species depredated crops and were vigorously controlled. As a result, several species have become extinct, most notably the Cuban Macaw Ara tricolor. Of those that survive, many are reduced in numbers and range, particularly with the increasing use of land for agriculture. Fully $22.8 \%$ (129 of 565 species) of Cuba's reptiles, amphibians, birds and mammals are considered in danger of extinction (Perera et al. 1993). Birds have fared somewhat better, but, of the 330 species of birds recorded for Cuba, $46(14 \%)$ are considered in danger of extinction (Perera et al. 1993). Among these are the Cuban Sandhill Crane Grus canadensis nesiotes and the Cuban Parrot Amazona leucocephala.

The Cuban Sandhill Crane is an endemic subspecies which is threatened with extinction throughout its range in Cuba and the Isla de la Juventud (Huerta et al. 1984, Perera et al. 1993). This species has long been of concern to conservationists because of its conspicuousness, large size and edibility (Gundlach 1893). Todd (1916) remarked that residents esteemed its flesh as food, and that cranes were shot for that purpose at every opportunity. Walkinshaw (1953) reported that during the winter of 1950-1951, hunters shot six cranes in the Isla de la Juventud, which at that time represented about $6 \%$ of the population. Although now legally protected from hunting, local people still consider it a game bird and it is shot for its flesh when the opportunity arises (Fernández Montaner 1968, García Montaña 1987).

Little is known about the Cuban Sandhill Crane's ecology and reproduction (Walkinshaw 1973), and its distribution and status have not been clearly determined. The crane's range diminished as natural savannas were converted for agriculture and other purposes. In the past century, Gundlach (1875) stated that cranes were common on some of the larger savannas of Cuba, including in the Isla de la Juventud. Indeed, in the mid-eighteenth century, Gundlach found Sandhill Cranes at Nueva Gerona, which is now the most developed part of the Isla de la Juventud (Poey 1851-1855). By the time of Gustav Link's explorations in the island (1912-1913), the crane was considered by no means common, but nevertheless a well-known and generally distributed bird (Todd 1916). Its range in the Isla de la Juventud has been described as limited to the flat country in the northern part of the island within the triangle of Santa Bárbara, Los Indios, and Santa [La] Fé (Fernández Montaner 1968, Walkinshaw and Baker 1946, Garrido 1985). Walkinshaw (1953) later refined his description of the crane's range in the island, stating that they were found north of the Ciénaga de Lanier (Lanier Swamp) from near Siguanea, north to Sierra de la Cañada, and west to West Port (directly west of Santa Bárbara), less often east to Pasadita and in winter to Sabana Grande.

Population estimates have varied widely. Link (in Todd 1916) estimated that he saw as many as 25 cranes during his years residence in the island. By 1945, all knowledgeable local observers remarked on how rare the crane was becoming (Walkinshaw and Baker 1946). But in 1951 Albert Vincent, a resident of the 
island, estimated a population of 100 cranes, as did another resident, Goya (Walkinshaw 1953). Walkinshaw (1953) suggested that the crane population had increased between his two visits in 1945 and 1951.

Recently, four isolated crane populations were recognized, with an estimated 30 individuals comprising each of these populations, including that of the Isla de la Juventud (Buide et al. 1974, Garrido and García 1975). We have located a total of nine populations in Cuban territories; two of these populations consist of more than 100 individuals, although good estimates of population sizes have not been made (Berovides and Gálvez 1994; Gálvez and Perera 1995; Gálvez et al. in press).

Once common throughout its island-wide range, the endemic Cuban Parrot is now considered by some as endangered in Cuba and the Isla de la Juventud (Buide et al. 1974, Huerta et al. 1984, Wiley 1991), although Stattersfield et al. (1998) list the parrot as "near threatened" and Collar et al. (1992) did not include it among those species classed as threatened. Aside from massive habitat loss, the parrot has been heavily persecuted for its depredation of the citrus crops in the Isla de la Juventud (Anonymous 1909, Todd 1916). During the 1930s, the citrus plantation owners established a bounty of 30 centavos per head for fruiteating birds, including the parrot (Gálvez 1996). Further population declines resulted from the harvesting of chicks for the pet trade. Link (in Todd 1916) related that one dealer was shipping about 2,100 young birds from the Isla de la Juventud in July 1912. Even with that large number, the dealer told Link that the parrot had been much more abundant. In fact, the Isla de la Juventud birds made up a large proportion of those for sale in La Habana markets at that time, because the parrot had disappeared from all but the most remote parts of Cuba (Smith 1944). The Cuban Parakeet Aratinga euops, formerly common in the Isla de la Juventud (Poey 1851-1855, Gundlach 1893), was also the subject of heavy harvesting for the pet trade. With the large-scale harvesting, the parrot and parakeet populations decreased in the island. By 1945, Walkinshaw and Baker (1946) described only small flocks of 2-25 parrots in grapefruit orchards, where they were eating the fruit, and at Rancho Rockyford, Santa Bárbara and Los Indios.

The parrot's steady decline prompted the Cuban government to establish legislation to limit its exportation for the pet trade at the end of the 1970 s and, in the 1980 , to initiate a programme for its re-establishment in the protected areas administered by the Empresa Nacional para la Conservación de la Flora y la Fauna. These efforts have resulted in the stabilization or increase of many populations (Gálvez and Berovides 1994, Berovides and Gálvez 1995). Unfortunately, these efforts came too late for some populations of the parakeet. It disappeared from the Isla de la Juventud by the twentieth century (Bangs and Zappey 1905, Todd 1916, Barbour 1943).

Both the parrot and the crane have been the subject of major conservation efforts in the Isla de la Juventud, particularly at the Ecological Reserve, "Los Indios", where they benefit from an aggressive management and conservation programme. Because we had no good population estimates which could be used to assay the effects of such management efforts, nor did good data exist on the distribution of the cranes and parrots outside Los Indios Reserve, a population survey of the two species was needed. To improve our knowledge of the species' population sizes and distribution, an intensive survey was conducted in northern 


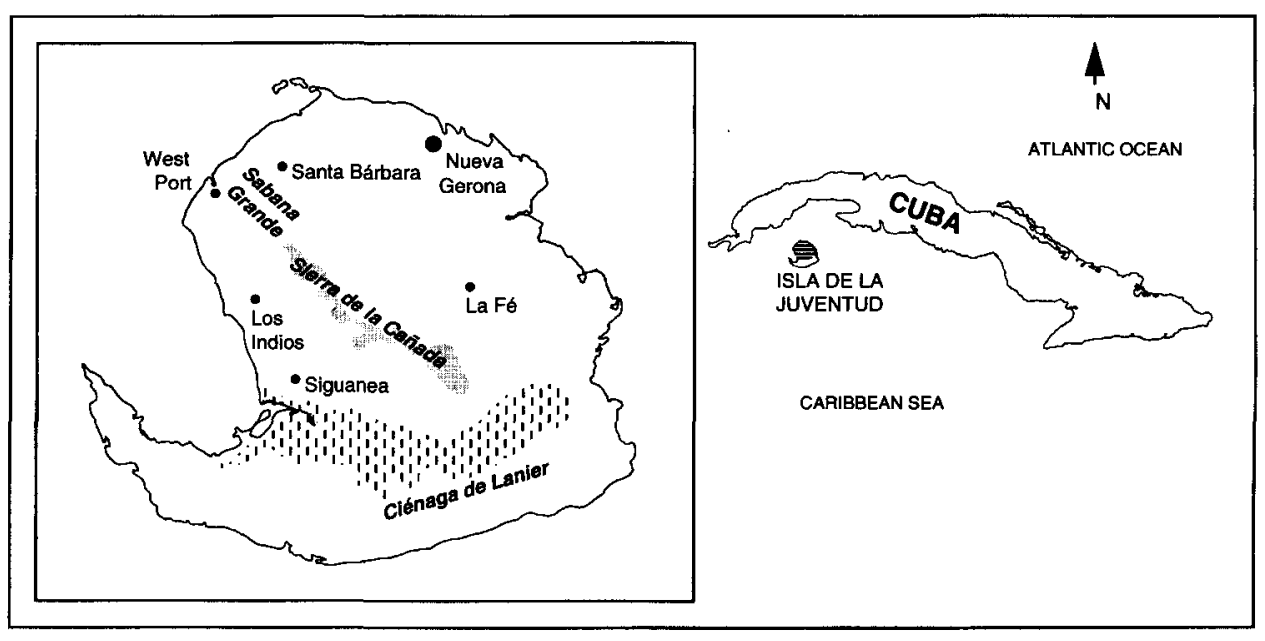

Figure I. Cuba and the Isla de la Juventud, with detail of the Isla.

Isla de la Juventud. Realizing that many efforts to save endangered species are dependent on public support, we developed an extensive programme of public education and involvement throughout the Isla de la Juventud. The programme was designed to increase public awareness of the endangered species and of conservation needs in general. As part of the programme, lay residents of the island were involved in the crane and parrot population surveys.

\section{Study area and methods}

The Isla de la Juventud is naturally divided by an east-west depression that forms the Ciénaga de Lanier (Figure 1). The region north of that depression is a domeshaped elevation of metamorphic Jurassic rock. We limited our surveys to the area of the Ciénaga de Lanier and north of the swamp. Jennings (1917) recognized 17 plant associations in the island. Among these, our surveys included the mangrove forest, riverbank (evergreen gallery) forest, arroyo, savanna, open forest, pinebarren, and tropical forest formations. The mangrove forest is characterized by black Avicennia germinans and red Rhizophora mangle mangroves. The riverbank forest formation is dominated by royal palm Roystonea regia, majagua Hibiscus tiliaceus, and bagá Annona glabra, as well as several smaller trees and shrubs, including Lonchocarpus latifolius, Hirtella mollicoma, Eugenia foramoides, and Ternstraemia obovalis. The arroyo formation includes Chrysobalanus pellocarpus, with other shrubs and smaller plants, including the tree-fern Alsophila myosuroides, and Adiantum fragile and A. cristatum. The savanna formation was formerly one of the most prominent and characteristic habitat types of the island, occupying most of the lower areas of the plain, excepting where the soils were too sandy. This formation continues as important, though it is much modified by agriculture. It is characterized by a considerable number of species of scraggly shrubs and palmettos, associated rather openly on a more or less grassy plain. The most characteristic shrubs are Byrsonima crassifolia, Miconia delicatula, Tabebuia lepidophylla, Brya ebences, Byrsonima verbasci- 


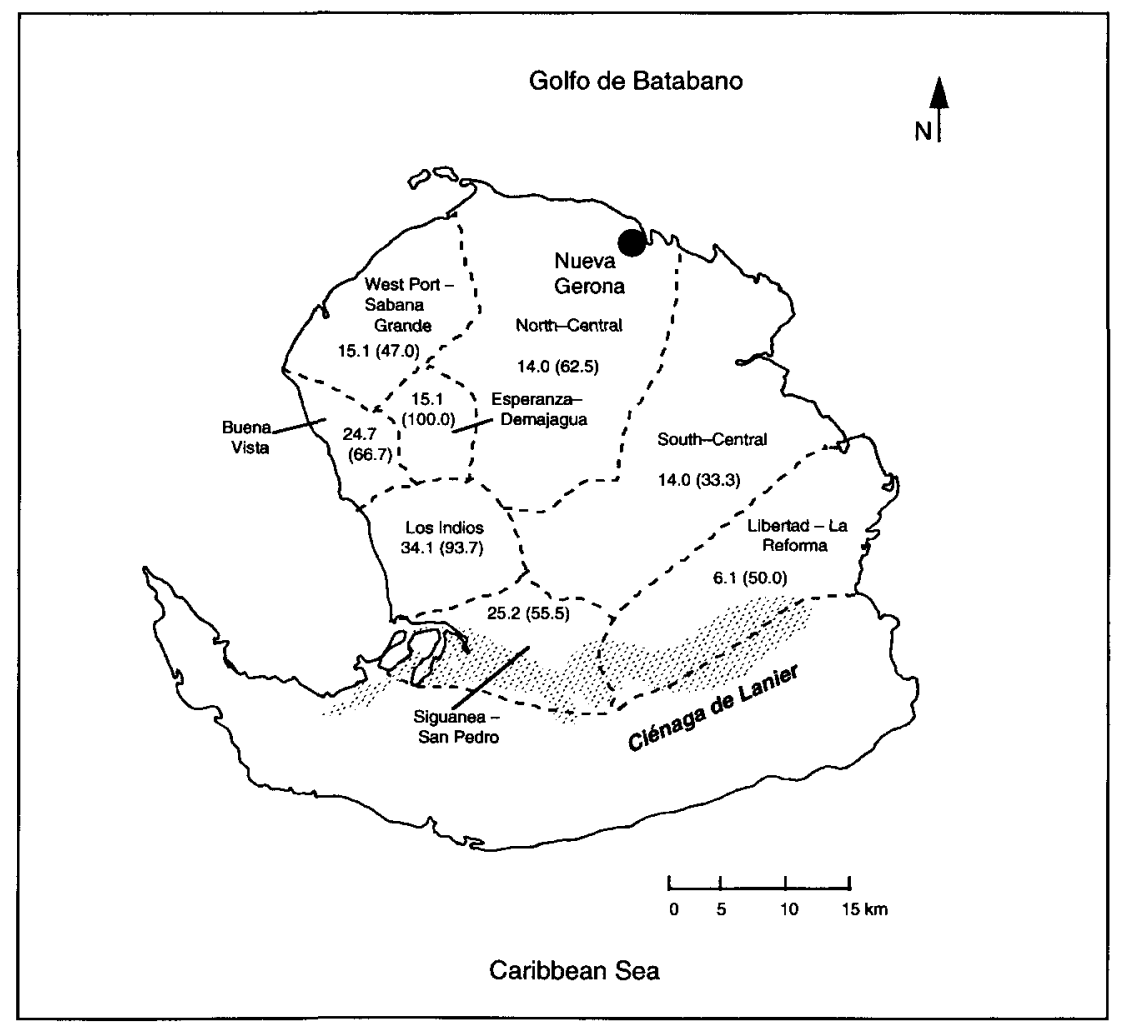

Figure 2. Abundance and distribution of Cuban Parrots among eight geographical zones (delimited by dashed lines) in northern Isla de la Juventud as determined by the 17 December 1995 survey. Figures within zones are mean number of parrots per station, with percentage of stations reporting parrot sightings in parentheses.

folia, and the palmetto Acoelorraphe wrightii. The open forest formation is characterized by open pine $P$. caribaea forest with palmettos and a sparse undergrowth of many of the species characteristic of the savanna. The pine-barren formation differs from the open forest in having acid soils and an undergrowth distinct from that of the savanna formation, and is composed characteristically of Pachyanthus cubensis, P. ovatus, Kalmiella aggregata, Miconia delicata, Polygala uncinata, Xolisma myrtilloides, Pinguicula filifolia, Stenorrhynchos squamalosus and Tetramicra eulophiae. This formation characterizes much of the white sands and gravel of Los Indios. The tropical forest formation consists of hardwoods covering the crystalline limestone hills and ridges, including the species Bombax emarginata, Sabal parviflora, Casearia sylvestris, Trichila hirta, Amyris balsamifera, and Cordia globosa. Because of the extensive economic development in the Isla de la Juventud, much of the natural environment has been modified.

We divided our survey sites among eight regions (Figure 2), which can be characterized as follows:

North-Central $\left(70.7 \mathrm{~km}^{2}\right)$ Flat plain with some modest rolling relief. Citrus plantations predominate, along with temporary crops, pine (Pinus caribaea and 
$P$. tropicalis) plantations, and a few patches of disturbed natural woods. Palma barrigona $C$. wrightii is dominant. Several reservoirs have been constructed. This region is adjacent to major towns and many isolated homes are distributed throughout.

South-Central $\left(106.1 \mathrm{~km}^{2}\right)$ Hills, dissected by small watersheds. Citrus and coffee plantations, and woods predominate. The area has been subject to little to considerable human disturbance. Sections of gallery forest are found along river beds. West Port-Sabana Grande $\left(71.6 \mathrm{~km}^{2}\right)$ Pastures predominate, with some areas now fallow. Some evergreen vegetation occurs in the wetter regions. This region is cattle range and is not occupied by people.

Buena Vista $\left(17.3 \mathrm{~km}^{2}\right)$ Natural palm savanna, with water-logged soils. No human settlements exist, but sand extraction creates high disturbance.

Esperanza-Demajagua $\left(34.6 \mathrm{~km}^{2}\right.$ ) Hilly relief, with pines (Pinus caribaea) and gallery forest forming continuous stands in the larger river beds. Human activity is low and occurs with seasonal crops.

Los Indios $\left(116 \mathrm{~km}^{2}\right)$ White sand savannas, with developed soils at the lower elevations and seasonally flooded depressions. Pine and palma barrigona predominate in woodland patches. In the east, cultivated pastures and a few forest and fruit plantations occur. The nearby town of La Victoria has a population of 2,000 people, but the reserve status of the area provides protection against human disturbance.

Siguanea-San Pedro $\left(82.2 \mathrm{~km}^{2}\right)$ Mostly flat, with low, scattered hills. Pastures, patches of natural woods with some human disturbance, seasonal crops, and evergreen vegetation along the river beds predominate. Seasonal flooding occurs in the lower elevations. The moderate number of scattered homes are mostly inhabited by farmers.

Libertad-La Reforma $\left(145 \mathrm{~km}^{2}\right)$ Flat to somewhat hilly relief, with pastures and seasonally flooded regions. Human influence is primarily associated with cattle grazing, although rice cultivation is also present.

Each of the above regions was characterized for soil types, topographic relief, and dominant vegetation (i.e. pines forest, woodland, palma barrigona, savannas and forest plantations). These characteristics were evaluated according to their positive (rating $=1$ ) or negative (o) values for parrots and cranes. An index was developed to determine the suitability of the habitat (i.e. region) for the two species:

$$
I=N_{H C} / \Sigma N_{H C} \times 100
$$

where $N_{H C}$ is the number of favourable habitat characteristics (i.e. sum of the 1s) and $\Sigma N_{H C}$ is the total number of habitat characteristics $(=6)$. This habitat quality index was compared with the relative abundance of the crane and parrot, determining their abundance as number of birds per station $\times$ occurrence per station. Associations of these ecological characteristics with parrot or crane presence will be used to further evaluate feeding, breeding, loafing and roosting habitats.

Our methods of population evaluation have been used with success in assessing other psittacine populations in the West Indies and for the Sandhill Crane in North America, but it is the first time that these methods have been used in Cuba. The survey method used to assess the crane population was 
adapted from that used by the International Crane Foundation, whereas that used for the parrot was adapted from methods used to estimate other populations of Amazona parrots in the West Indies (e.g. Snyder et al. 1987, Gnam and Burchsted 1991).

Through aerial and ground-level inspections throughout the island we identified probable habitats of both species and plotted these areas on maps. These areas were characterized for human use and vegetative attributes. We also made enquiries among residents to gather information on the present and past local history of crane and parrot use of the areas. As a result of the interviews and inspections, survey stations were established at sites likely to have parrots or cranes. A total of 98 stations were established, each separated by at least $2 \mathrm{~km}$. The total area covered in the survey was $643.5 \mathrm{~km}^{2}$ (29\% of the $2,200-\mathrm{km}^{2}$ island). The survey was conducted in December to avoid the breeding (February-June) and hurricane (June-November) seasons.

Before the main census involving the local community, we conducted preliminary surveys throughout the study area to test stations and to establish a general estimate of crane and parrot distribution which would be compared with the comprehensive, simultaneous census on 17 December. Each morning (o5hoo1ohoo; sunrise o7hoo) and evening (16hoo-18h30; sunset $17 \mathrm{~h} 50$ ) from 11 to 16 December 1995, 6-8 stations were manned by us and identification-skilled associates. During this period we refined data collection forms to better suit our needs and to simplify the forms for use by the volunteers.

Public involvement was solicited in many ways. Attractive posters showing the parrot and crane were designed to recruit volunteers and to announce public information and training sessions held in Nueva Gerona (the island's largest town) and La Victoria, nearest to Los Indios Ecological Reserve. Local press, radio and television media were extensively used in an environmental education campaign, and to inform the general public of the objectives and results of the survey. Local artisans were encouraged to produce parrot- and crane-theme objects in several media.

More than 300 people from throughout the island volunteered to participate in the survey. A maximum of three lay volunteers were assigned to each station. Among the participants were 105 volunteers who had previous experience in bird identification, such as university biology students, members of hunting clubs, and personnel of the corps of forest guards. These experienced participants served as coordinators, and each was responsible for the organization and training of the volunteers at five survey stations. In the month before the survey the coordinators received extensive training during 16 conference sessions. Each coordinator received a file of information on the parrot and crane, along with census data forms, and instructions on survey protocol with which they could become familiar with these materials and pass them on to their assigned team of lay volunteers. Before the survey all volunteers received training in bird identification and data collection using standardized data sheets.

Given the difficulties of transportation in the island, we assigned participants to observation stations near their homes. The coordinators used some means of transport (e.g. horse, bicycle, tractor) to maintain contact with the participants at their five assigned stations. However, most of the participants travelled to and from their stations on foot, some for long distances. The survey involving the 
Table 1. Numbers of Cuban Parrots and Sandhill Cranes observed per station by region, northern Isla de la Juventud, Cuba, 17 December 1995

\begin{tabular}{|c|c|c|c|c|c|}
\hline \multirow[t]{2}{*}{ Region } & \multirow{2}{*}{$\begin{array}{l}\text { Number } \\
\text { of } \\
\text { stations }\end{array}$} & \multicolumn{2}{|c|}{ Parrots } & \multicolumn{2}{|c|}{ Cranes } \\
\hline & & $\begin{array}{l}\text { Mean number } \\
\text { per station }\end{array}$ & $\begin{array}{c}\text { Occurrence } \\
\text { per station (\%) }\end{array}$ & $\begin{array}{l}\text { Mean number } \\
\text { per station }\end{array}$ & $\begin{array}{c}\text { Occurrence } \\
\text { per station (\%) }\end{array}$ \\
\hline North-Central & 8 & 14.0 & 62.5 & 0 & 0 \\
\hline South-Central & 21 & I4.0 & 33.3 & 3.0 & 23.8 \\
\hline West Port-Sabana Grande & 17 & 15.1 & 47.0 & 3.9 & 70.5 \\
\hline Buena Vista & 6 & 24.7 & 66.7 & 2.2 & 66.7 \\
\hline Esperanza-Demajagua & 7 & 15.1 & 100.0 & $3 \cdot 3$ & 42.8 \\
\hline Los Indios & 16 & 34.1 & 93.7 & 3.6 & 56.2 \\
\hline Siguanea-San Pedro & 9 & 25.2 & 55.5 & 2.2 & 55.5 \\
\hline Libertad-La Reforma & 14 & 6.1 & 50.0 & 0 & 0 \\
\hline Total & 98 & 22.3 & 59.2 & 3.0 & 38.7 \\
\hline
\end{tabular}

public was conducted on 17 December 1995 from o6hoo to 10 hoo (participants were at their stations by about 05 hool. This period ensured maximum detection of parrot activity. At a minimum, all crane and parrots detected at a station were recorded. Each observation was noted along with time of sighting, nature of the bird's activity (e.g. flying, perched, foraging, calling) and direction of flight. Data sheets were collected by the group coordinator at the end of the survey. That coordinator worked with us in analysing the survey results for their area of responsibility.

Following the survey, all participants were transported to the town of La Victoria, where a public festival closed the event. Among the festival activities, awards and prizes were presented to students (primary through high school) who had prepared outstanding artwork, poems and essays using conservation as the theme. Local artisans sold their crane- and parrot-theme wares to the tourists. A street dance, with a parrotcostumed disc jockey, continued until o2h3o the next morning.

\section{Results and discussion}

\section{Cuban Parrot distribution and population size}

Weather during the survey was excellent, with little wind and no rain, which allowed excellent visibility and sound detection. We observed parrots at 60 $(61.2 \%)$ of the 98 stations. The total maximum (without correcting for repeated sightings) number of parrots was 1,320 individuals. After correcting for possible duplication in counting individuals among stations, the minimum number of parrots found in the northern region of the Isla de la Juventud was determined to be 1,100 individuals. It is known that approximately 600 parrots breed at Los Indios Ecological Reserve (Gálvez and Berovides 1992), which thereby represents $54.5 \%$ of the estimated population for the entire northern region of the Isla de la Juventud. The Los Indios region had the highest numbers of parrots observed per station and the second highest percentage of stations with parrot sightings (Table 1, Figure 2). These data support the importance of the Ecological Reserve 
Table 2. Frequency of Cuban Parrots (minimum numbers) detected per station during the population survey in northern Isla de la Juventud, Cuba, 17 December 1995

\begin{tabular}{lcc}
\hline No. observed per station & \multicolumn{2}{c}{ Frequency } \\
\cline { 2 - 3 } & Number & $\%$ \\
\hline $1-10$ & 26 & $43 \cdot 3$ \\
$11-20$ & 16 & 26.7 \\
$21-30$ & 71 & 1.7 \\
$31-40$ & 3 & 5.0 \\
$41-50$ & 2 & $3 \cdot 3$ \\
$51-60$ & 1 & 1.7 \\
$61-70$ & 1 & 1.7 \\
$71-80$ & 0 & 0 \\
$81-90$ & 2 & $3 \cdot 3$ \\
$\geq 91$ & 2 & $3 \cdot 3$ \\
Total & 60 & 100.00 \\
\hline
\end{tabular}

for the protection and management of the Cuban Parrot in the northern part of the Isla de la Juventud.

Of those stations where parrots were recorded, most $(n=26 ; 43.3 \%)$ reported low (1-10) or modest (11-20; $26.7 \%$ ) minimum numbers of individuals (Table 2). A mean of 22.3 parrots was detected per station reporting birds, with a range of 1-145 individuals.

We assessed the geo-ecological characteristics of the eight regions of the northern part of the island (Table 3). The most diverse habitats in all ecological aspects surveyed are at Los Indios and Siguanea-San Pedro. The highest mean values for parrot sightings per observation point (almost always double the average per station) were associated with sandy soils, flat lands, those areas likely to be flooded (with nearby mangroves), and with the presence of all types of vegetation (Table 4). Among the habitat characteristics we measured, perhaps the most important was the presence of pines interspersed with palma barrigona, because a high relative abundance of parrots was also reported at Buena Vista, where pines and palms predominate. Although this region showed a low diversity of habitat, pine cones are an important part of the parrot's diet (Gálvez et al. in press), to the extent that food reserves at Buena Vista were excellent. We found no substantial differences in parrot distribution between our comprehensive survey on 17 December and the preliminary surveys conducted earlier in the week to test stations.

The habitat quality index derived for each region was weakly related $(r=0.4)$ to the abundance of parrots observed per site, except in Buena Vista, where the high number of parrots observed may be associated with presence of pines with palma barrigona (Table 5).

\section{Sandhill Crane distribution and population size}

Cranes were observed at $38(38.8 \%)$ of the 98 stations. The total maximum number of cranes counted was 115 birds, which is similar to the 100 birds suggested by Johnsgard (1983) for the Isla de la Juventud population. No corrections 


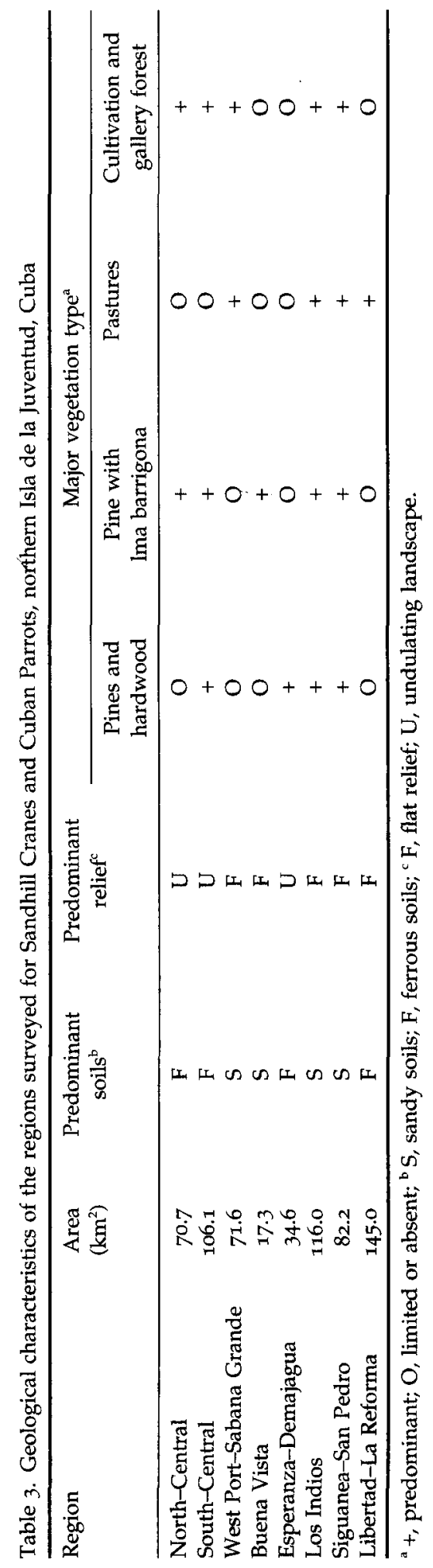


were made for repeated counts for cranes and, following careful analysis of the census data, we believe there was a low probability of counting any of the birds more than once. A mean of 3.3+1.9 (range 1-8) individuals per successful station was recorded. The number of individuals observed per sighting had a mode of 2, which agrees with the fact that adult cranes normally remained paired throughout the year (Walkinshaw 1973) (Table 6). We observed a total of 51

Table 4. Physical and ecological factors that favour the abundance of the Cuban Parrot and Sandhill Crane in northern Isla de la Juventud, Cuba. Mean parrot and crane abundance per survey station characterized by the physical or ecological variable is presented in parentheses

\begin{tabular}{lcccc}
\hline Variable & \multicolumn{3}{c}{ Condition relative to bird abundance } \\
\cline { 2 - 5 } & \multicolumn{2}{c}{ Parrot } & Crane \\
\cline { 2 - 5 } & Favourable & Unfavourable & Favourable & Unfavourable \\
\hline Soils & Sandy(30.5) & Ferrous (12.2) & Sandy (1.8) & Ferrous (1.0) \\
Flat terrain, prone to flooding, with & Present (26.1) & Absent (14.4) & Present (1.8) & Absent (1.0) \\
$\quad$ mangroves & & & & \\
Pines and mixed forest & Present (25.8) & Absent (17.2) & Absent (2.1) & Present (1.3) \\
Pines with palma barrigona & Present (28.4) & Absent (15.1) & Absent (2.1) & Present (1.3) \\
Savanna with pastures & Present (24.0) & Absent (19.7) & Present (2.0) & Absent (1.2) \\
Gallery forest with some cultivation & Present (24.1) & Absent (18.2) & Present (1.6) & Absent (1.4) \\
\hline
\end{tabular}

Table 5. Comparison of values derived from a habitat quality index with mean frequencies of Cuban Parrots and Sandhill Cranes detected per station in eight regions in northern Isla de la Juventud

\begin{tabular}{lccccc}
\hline Region & \multicolumn{2}{c}{ Parrots } & & \multicolumn{2}{c}{ Cranes } \\
\cline { 2 - 3 } \cline { 5 - 6 } & $\begin{array}{c}\text { Habitat } \\
\text { quality index }\end{array}$ & $\begin{array}{c}\text { Mean number } \\
\text { of per station }\end{array}$ & $\begin{array}{c}\text { Habitat } \\
\text { quality index }\end{array}$ & $\begin{array}{c}\text { Mean number } \\
\text { of per station }\end{array}$ \\
\hline North-Central & 0.33 & 8.7 & - & - \\
South-Central & 0.50 & 4.6 & & 0.16 & 0.7 \\
West Port-Sabana Grande & 0.67 & 7.1 & & 1.00 & 2.7 \\
Buena Vista & 0.50 & 29.8 & & 0.50 & 1.5 \\
Los Indios & 1.00 & 34.4 & & 0.67 & 2.0 \\
Siguanea-San Pedro & 1.00 & 13.9 & & 0.67 & 2.2 \\
Libertad-La Reforma & 0.33 & 3.1 & & - & - \\
Esperanza-Demajagua & 0.16 & 15.1 & 0.16 & 1.4 \\
\hline
\end{tabular}

Table 6. Frequency of Sandhill Cranes detected per observation point during the population survey in northern Isla de la Juventud, Cuba, 17 December 1995

\begin{tabular}{lrr}
\hline No. observed per station & \multicolumn{2}{c}{ Frequency } \\
\cline { 2 - 3 } & $n$ & $(\%)$ \\
\hline 1 & 3 & $7 \cdot 9$ \\
2 & 17 & $44 \cdot 7$ \\
3 & 5 & 13.2 \\
4 & 3 & 7.9 \\
5 & 5 & 13.2 \\
6 & 1 & 2.6 \\
7 & 3 & 7.9 \\
8 & 1 & 2.6 \\
Total & 38 & 100.00 \\
\hline
\end{tabular}




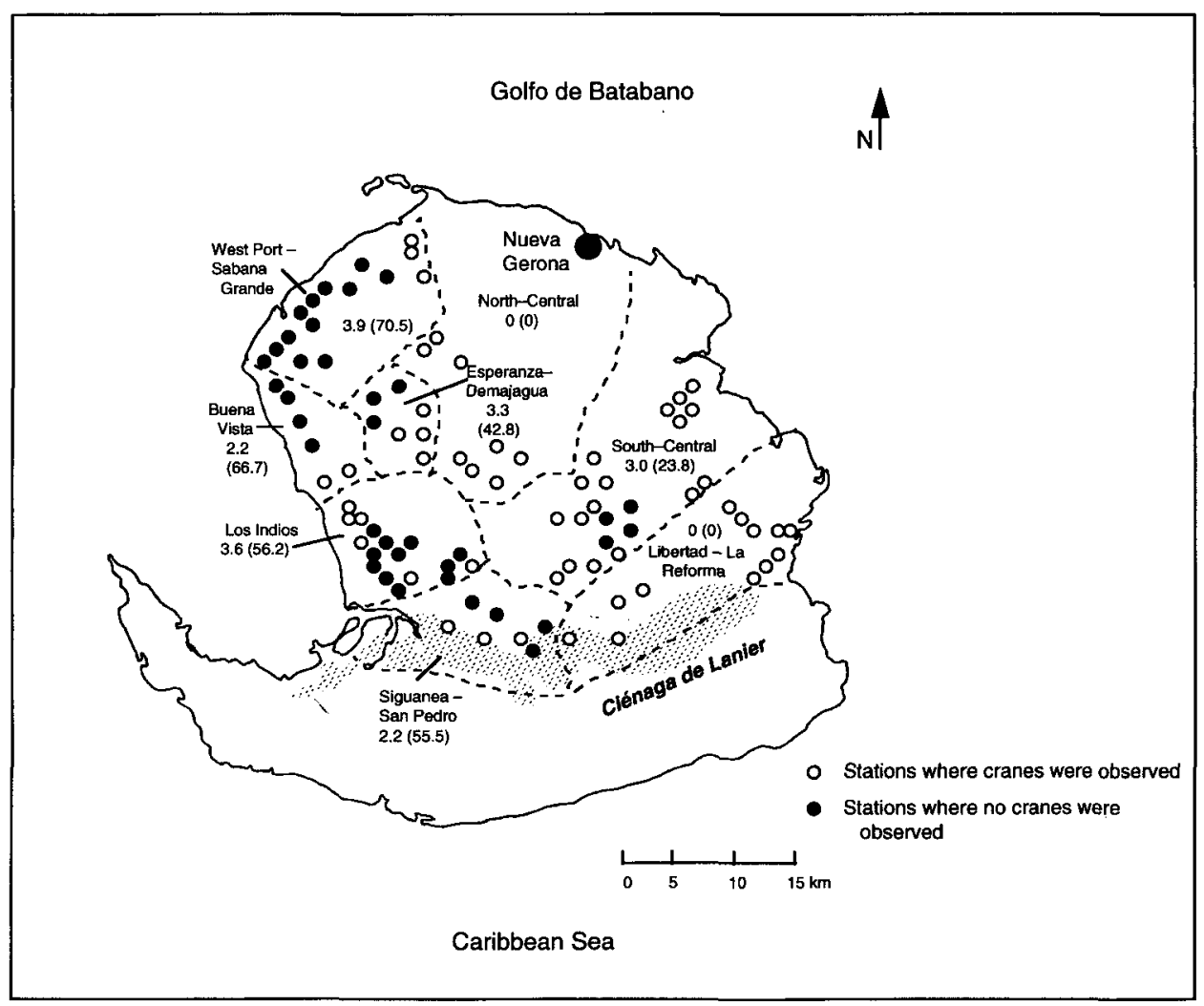

Figure 3. Abundance and distribution of Sandhill Cranes at survey stations within eight geographical zones (delimited by dashed lines) in northern Isla de la Juventud, 17 December 995 . Figures within zones are mean number of cranes per station, with percentage of stations reporting crane sightings in parentheses.

pairs of adult cranes, which suggests a reproducing population of about 100 individuals.

Among the eight zones, the highest number of cranes per station was detected at Sabana Grande, a largely uninhabited area. The two areas with highest human disturbance (North-Central and Libertad-La Reforma) yielded no crane sightings (Table 1, Figure 3). Los Indios Ecological Reserve had the second highest number of cranes recorded per station (3.6), with low occurrence at only one station (Table 1). Other regions with high mean numbers of cranes per station included West Port-Sabana Grande (3.9), Esperanza-Demajagua (3.3), and South-Central (3.0). These results suggest that several additional sites should be considered for protecting the crane.

Our analyses revealed that the ecological conditions favoured by foraging cranes appear to be sandy soils, flat relief areas prone to flooding, absence of pines and woodlands, and presence of pasture-landsavannas (Table 4). Our habitat quality index was a good predictor $(r=0.8)$ of crane abundance (Table 5). Crane distribution suggested by the preliminary surveys was similar to that determined during the community participation survey on 17 December. 
Table 7. Coincidence of Sandhill Cranes and Cuban Parrots at survey stations, northern Isla de la Juventud, Cuba, 17 December 1995

\begin{tabular}{llccc}
\hline \multirow{2}{*}{ Species } & None & No stations & \multicolumn{2}{c}{ Stations where detected } \\
\cline { 4 - 5 } & & & $n$ & $(\%)$ \\
\hline Cranes and parrots & & 8 & 0 & 0 \\
& North-Central & 21 & 1 & 4.7 \\
& South-Central & 17 & 4 & 23.5 \\
& West Port-Sabana Grande & 6 & 3 & 33.3 \\
& Buena Vista & 7 & 3 & 42.8 \\
& Esperanza-Demajagua & 16 & 8 & 50.0 \\
& Los Indios & 9 & 2 & 22.2 \\
& Siguanea-San Pedro & 14 & 0 & 0 \\
Only cranes & Libertad-La Reforma & 98 & 20 & 20.4 \\
Only parrots & Total & 98 & 18 & 18.3 \\
Both species absent & & 98 & 38 & 38.7 \\
\hline
\end{tabular}

\section{Co-occurrence of cranes and parrots}

Based on our pre-survey aerial and ground-level inspections, and interviews with residents, we predicted that 20 of our stations would be suitable for both crane and parrot populations. In fact, both species were recorded from 20 $(20.4 \%)$ of the stations (Table 7 ). In two of the regions, including Los Indios Ecological Reserve, more than $40 \%$ of stations had cranes and parrots sighted together. These results affirm the value of this reserve in protecting both species. Los Indios Ecological Reserve provides not only feeding habitat, but is also an important breeding site, particularly for the crane, which does not fare well in sites with human disturbance.

\section{Effectiveness of the education campaign}

The education programme has had an initial positive effect on the residents of the Isla de la Juventud, with most citizens now aware of the conservation problems in their unique island, and particularly of the need for conservation programmes for the crane and parrot. There is a widespread appreciation among residents for the distinct nature of the avifauna of their island, and particularly a sense of pride in the uniqueness of the crane and parrot to their country. Various designs using endangered and other native species have been incorporated into the small tourist souvenir trade of the island. Two years after the event, island residents frequently ask us about the status of "their" cranes and parrots. There have also been numerous requests from island government officials and residents for additional festivals that would continue to inform the public and protect their natural resources.

\section{Future work}

As part of a continuing conservation project in the Isla de la Juventud we plan to determine all feeding and breeding zones of the two species through follow-up 
surveys to areas where birds were found during the December 1995 count. We will then broaden our current studies to include a more detailed characterization of the habitat of those zones to provide direction for management operations favourable to the conservation of both species. We recommend repeating this survey every 2 years, with the objective of monitoring population levels and to maintain contact with the local human population in a continuing effort to improve environmental education and develop a conservation ethic.

We will be using these survey and public involvement methods in other provinces of Cuba, giving priority to those regions where both species exist in good numbers. We propose the province of Ciego de Ávila as the site for the next survey, where healthy populations of parrots and cranes coexist, along with the endangered Cuban Parakeet, and where the Empresa de Flora y Fauna has a conservation programme for these three species.

We believe that the survey and education programme combined can be applied to conservation of other endangered species by providing direct communication with the local human populations, who can thereby gain an active appreciation for conservation.

\section{Acknowledgements}

We gratefully acknowledge the support of the International Crane Foundation, Brehm Foundation; Wildlife Preservation Trust International, Inc.; RARE Center for Tropical Conservation; World Parrot Fund; and BirdLife International. Rafael Carbonell Paneque, Julia Rodríguez Bacallao, Efrén Iznaga Palacio and Luis Hernández García generously provided logistical assistance in the Isla de la Juventud and helped in other ways. Orlando Garrido, Lourdes Mugica, Martín Acosta, Patricia Wainright, Ian Lothian and Robert and Dian Rattner generously donated their time in helping to field test stations and methodology before the survey, for which we are grateful. We are particularly grateful to Fidel Quiala G., and other members of the Los Indios staff, for their assistance in all field phases of the project. Most of all, we greatly appreciate the enthusiastic participation and support of the people of the Isla de la Juventud.

\section{References}

Anonymous. (1909) Cuban parrots and politics. Forest and Stream 73: 365.

Bangs, O. and Zappey, W. R. (1905) Birds of the Isle of Pines. Am. Nat. 39: 179-215.

Barbour, T. (1943) Cuban ornithology Mem. Nuttall Orn. Club No. 9, Cambridge, Mass.

Berovides, V. and Gálvez, X. (1994) Caracterizacion ecologica de la avifauna cubana en peligro de extincion. Pitirre $7(3): 6$.

Berovides, V. and Gálvez, X. (1995) Situacion poblacional de la grulla cubana (Grus canadensis nesiotes). Rev. Cub. Cier. Vet. 24: 3-5.

Buide, M., Fernández, J., Garcia Montaña, F., Garrido, O. H., de los Santos Izquierdo, H., Silva, G. and Varona, L. (1974) Las especies amenazadas de vertebrados cubanos. La Habana: Academia de Ciencias.

Collar, N. J., L. P. Gonzaga, N. Krabbe, A. Madrono Nieto, L. G. Naranjo, T. Parker III, and D. C. Wege. 1992. Threatened birds of the Americas. ICBP/IUCN Red Data Book, third edition. Washington, D. C.: Smithsonian Institution Press.

Cuevas, J. R. (1997) An assessment of biodiversity in Cuba. Inter-Am. Dialogue 4: 23-30.

Fernández Montaner, D. A. (1968) Aves de caza de Cuba. La Habana: Ediciones Deportivas. Gálvez Aguilera, X. (1996) Los psitacidos del archipielgo cubano. Flora y Fauna 0: 34-35. 
Gálvez Aguilera, X. and Berovides, V. (1992) Estudio de una población de Cotorra Cubana, Área Protegida "Los Indios", Isla de la Juventud. La Habana: Empresa Nacional para la Protección de la Flora y la Fauna.

Gálvez, X. and Berovides, V. (1994) Status de los psitacidos cubanos en las areas protegidas. P. 81 in Internatn. Meeting Soc. Conserv. Biol. Guadalajara, Mexico (abstract).

Gálvez, X. and Perera, A. (1995) A crane conservation revival in Cuba. The ICF Bugle 1: 2-3.

Gálvez Aguilera, X., Rivera R., J., Quiala G., F. and Wiley, J. W. (in press) Breeding season diet of the Cuban Parrot (Amazona leucocephala) in the Los Indios Ecological Reserve, Isla de la Juventud, Cuba. Papageienkunde.

García Montaña, F. (1987) Las aves de Cuba: subespecies endémicas, II. La Habana: Editorial Gente Nueva.

Garrido, O. H. (1985) Cuban endangered birds. Pp. 992-999 in P. A. Buckley, M. S. Foster, E. S. Morton, R. S. Ridgely and F. G. Buckley, eds. Neotropical ornithology. Washington, D. C.: American Ornithologists' Union (Ornithological Monograph No. 36).

Garrido, O. H. and García Montaña, F. (1975) Catálogo de las aves de Cuba. La Habana: Academia de Ciencias.

Gnam, R. and Burchsted, A. (1991) Population estimates for the Bahamas Parrot on Abaco Island, Bahamas. J. Field Orn. 62: 139-146.

Gundlach, J. (1875) Neue beiträge zur ornithologie Cubas. Nach eigenen 30 jährigen beobachtungen zusammengestellt. J. Orn. 23(131): 293-340.

Gundlach, J. (1893) Ornithología cubana ó catálogo descriptivo de todas las especies de aves tanto indígenas como de paso annual o accidental observadas en 53 años. La Habana: Archivos de la Policlínica ed. Imprenta "La Moderna."

Huerta Losada, T., Berovides Alvarez, V. and Sánchez, B. (1984) Comunidad de aves de las sabanas arenosas de la Isla de la Juventud. Informe Preliminar. P. 457 in IV Conferencia Cientifica sobre Educación Superior, 1984. La Habana: Universidad de La Habana.

Instituto Cubano de Geodesia y Cartografía. (1978) Atlas de Cuba. XX Aniversario del Triunfo de la Revolución. La Habana: Instituto Cubano de Geodesia y Cartografía.

Jennings, O. E. (1917) A contribution to the botany of the Isle of Pines, Cuba, based upon the specimens of plants from that island contained in the Herbarium of the Carnegie Museum under date of October 1916. Ann. Carnegie Mus. 11(1-2): 19-29o.

Johnsgard, P.A. (1983) Cranes of the World. Bloomington: Indiana University Press.

Perera, A., Garrido, O., Estrada, J. and González, H. (1993) Especies de vertebrados amenazadas. Habana, Cuba.

Poey, F. (1851-1855) Apuntes sobre la fauna de la Isla de Pinos. Pp. 424-431 in Memorias sobre la Historia Natural de la Isla de Cuba, acompañadas de sumarios Latinos y extractos en Frances, 1. Habana: Imprenta de Barcina.

Smith, H. L. (1944) Chirpings from Cuba. Aviculture 14: 217-221.

Snyder, N. F. R., Wiley, J. W. and Kepler, C. B. (1987) The parrots of Luquillo: the natural history and conservation of the Puerto Rican parrot. Los Angeles: Western Foundation of Vertebrate Zoology.

Stattersfield, A. J., M. J. Crosby, A. J. Long and D. C. Wege. (1998) Endemic bird areas of the world: priorities for biodiversity conservation. Cambridge, U.K.: BirdLife International (BirdLife Conservation Series No. 7).

Todd, W. E. C. (1916) The birds of the Isle of Pines. Incorporating the substance of fieldnotes by Gustav A. Link. Ann. Carnegie Mus. 10: 146-296.

Walkinshaw, L. H. (1953) Nesting and abundance of the Cuban Sandhill Crane on the Isle of Pines. Auk 70: 1-10.

Walkinshaw, L. H. (1973) Cranes of the world. New York: Winchester Press. 
Walkinshaw, W. H. and Baker, B. W. (1946) Notes on the birds of the Isle of Pines, Cuba. Wilson Bull. 58: 133-142.

Wiley, J. W. (1991) Status and conservation of parrots and parakeets in the Greater Antilles, Bahama Islands, and Cayman Islands. Bird Conserv. Internatn. 1: 187-214.

\section{XIOMARA GÁLVEZ AGUILERA}

Empresa Nacional para la Conservación de la Flora y la Fauna, Ministerio de la Agricultura, La Habana, Cuba.

\section{VICENTE BEROVIDES ALVAREZ}

Facultad de Biología, Universidad de la Habana, La Habana, Cuba.

\section{JAMES W. WILEY}

Biological Resources Division, U. S. Geological Survey, Reston, Virginia 22092, USA; Mailing address: Grambling Cooperative Wildlife Project, P. O. Box 841, Grambling State University, Grambling, Louisiana 71245, USA. E-mail: wileyjw@alphao.gram.edu

\section{JOSÉ RIVERA ROSALES}

Empresa Nacional para la Conservación de la Flora y la Fauna, Ministerio de la Agricultura, Nueva Gerona, Isla de la Juventud, Cuba. 